\title{
Biogeographical homogeneity in the eastern Mediterranean Sea. II. Temporal variation in Lebanese bivalve biota
}

\author{
Fabio Crocetta $^{1, *}$, Ghazi Bitar $^{2}$, Helmut Zibrowius $^{3}$, Marco Oliverio ${ }^{4}$ \\ ${ }^{1}$ Stazione Zoologica Anton Dohrn, Villa Comunale, 80121, Napoli, Italy \\ ${ }^{2}$ Department of Natural Sciences, Faculty of Sciences, Lebanese University, Hadath, Lebanon \\ ${ }^{3}$ Le Corbusier 644, 280 Boulevard Michelet, 13008 Marseille, France \\ ${ }^{4}$ Dipartimento di Biologia e Biotecnologie ‘Charles Darwin', University of Rome ‘La Sapienza', Viale dell'Università 32, \\ 00185 Roma, Italy
}

\begin{abstract}
Lebanon (eastern Mediterranean Sea) is an area of particular biogeographic significance for studying the structure of eastern Mediterranean marine biodiversity and its recent changes. Based on literature records and original samples, we review here the knowledge of the Lebanese marine bivalve biota, tracing its changes during the last $170 \mathrm{yr}$. The updated checklist of bivalves of Lebanon yielded a total of 114 species (96 native and 18 alien taxa), accounting for ca. $26.5 \%$ of the known Mediterranean Bivalvia and thus representing a particularly poor fauna. Analysis of the 21 taxa historically described on Lebanese material only yielded 2 available names. Records of 24 species are new for the Lebanese fauna, and Lioberus ligneus is also a new record for the Mediterranean Sea. Comparisons between molluscan records by past (before 1950) and modern (after 1950) authors revealed temporal variations and qualitative modifications of the Lebanese bivalve fauna, mostly affected by the introduction of Erythraean species. The rate of recording of new alien species (evaluated in decades) revealed later first local arrivals (after 1900) than those observed for other eastern Mediterranean shores, while the peak in records in conjunction with our samplings (1991 to 2010) emphasizes the need for increased field work to monitor their arrival and establishment. Finally, the scarce presence (or total absence) in the most recent samples of some once common habitat-forming species, as well as of some other native taxa, confirmed their recent rarefaction (or local extinction), possibly related to their replacement by the aliens Brachidontes pharaonis, Spondylus spinosus and Chama pacifica.
\end{abstract}

KEY WORDS: Mediterranean Sea $\cdot$ Lebanon $\cdot$ Mollusca $\cdot$ Bivalvia $\cdot$ Alien species $\cdot$ Faunal changes

\section{INTRODUCTION}

The present-day autochthonous Mediterranean marine fauna is mostly of Atlantic origin, having originated with the re-establishment of the AtlantoMediterranean connection (5.33 million years ago), after the Messinian Salinity Crisis (from 5.971 to 5.33 million years ago; Manzi et al. 2013) had probably nearly exterminated the stenoecious marine biota (Sabelli \& Taviani in press). The subsequent 5 million years of evolution within the framework of the complexity of the basin gave rise to the peculiar and variegate Mediterranean assemblage, with the co-occurrence of temperate and subtropical organisms and a main transitional zone between the 2 seas (the Alboran Sea), hosting a mix of Mediterranean and Atlantic species (Bianchi \& Morri 2000, Oliverio 2003, Coll et al. 2010).

The opening of the Suez Canal in the south-eastern corner of the Mediterranean in 1869 contributed to changes in the local biodiversity and provided an additional human-induced transitional zone. The spreading of alien species (used here as defined by 
the International Union for Conservation of Nature, see Crocetta 2012) has become one of the main local phenomena affecting species distribution and composition within assemblages (Por 1978, Galil 2009). Mainly confined for over a century along the Levant Sea, alien species of thermophilic origin are currently spreading further to the western and northern Mediterranean, presumably favoured by the general warming of the area (Occhipinti-Ambrogi 2007, Raitsos et al. 2010). Present-day local biodiversity, which is currently threatened by habitat loss and degradation, fishing impacts, pollution, climate change and eutrophication, is also impacted by alien introduction through human activities (e.g. aquaculture, shipping and leisure boating). Prevention and/or control of alien species diffusion have therefore become a major challenge for conservationists (Galil 2009, Zenetos et al. 2012), and the cumulative impact of these biotic and abiotic changes is resulting in the disruption of the original biogeographic pattern within the basin, with several authors drawing attention to the progressive homogenization of Mediterranean marine biota (Bianchi 2007, Lejeusne et al. 2010, Philippart et al. 2011).

The Mediterranean molluscan fauna is considered as the best known in the world, and numerous detailed taxonomic inventories now exist, most of which are specific to sub-regions or countries (Oliverio 2003, Coll et al. 2010). Mollusca, as a 'popular' and thus frequently investigated group, comprise the highest number of known introduced species in the Mediterranean. There are now an estimated $\sim 200$ introduced species, more than half of which are with established populations, indicating a high rate of introduction and accounting for $\sim 10 \%$ of the Mediterranean Mollusca (slightly more than 2000 species) (Coll et al. 2010, Zenetos et al. 2012). Despite continuous efforts to provide updated datasets for the entire basin, our knowledge of the Levantine area still remains considerably poor when compared with the central and western basin. This is probably due to undersampling due to the absence of recent faunal projects.

Our knowledge of Lebanese marine fauna has a similar history to the rest of the Levant basin. Early pioneering papers provided accurate data on shelled molluscs from 1856 to 1938, while the following decades were rather unfertile until 1971. From then up until 2013, less than 30 papers, notes, abstracts and non-peer-reviewed articles have provided additional scattered information on Lebanese marine bivalve molluscs (Puton 1856, Brusina 1879, Pallary 1911, 1912a, 1919, 1933, 1938, Gruvel \& Moazzo 1929, Gruvel 1931, Moazzo 1931, Spada 1971, Fadlallah 1975,
Shiber \& Shatila 1978, Shiber 1980, Zibrowius \& Bitar 1981, 2003, Bogi \& Khairallah 1987, Bitar 1996, 2010, 2013, Bitar \& Kouli-Bitar 1995a,b, 1998, 2001, Nakhlé et al. 2006, Bitar et al. 2007, Bariche 2012, Crocetta \& Russo 2013). However, wide-ranging overviews of the temporal trends and the long-term faunal changes occurring in the area are still lacking.

Using material obtained on field trips within the Programme CEDRE (French-Lebanese cooperation) from 1999 to 2002, enriched by some additions from earlier and later years, this study is the most complete overview of the marine Bivalvia of Lebanon. It aims at: (1) providing an updated checklist of marine bivalve species recorded in Lebanon; (2) investigating historical taxon names based on Lebanese type material and checking their availability as a contribution to Mediterranean bivalve taxonomy; (3) focusing on alien bivalves in Lebanon, providing a checklist of published and unpublished records, with date of the first record, most plausible vector(s) of introduction and the establishment status; and (4) tracing temporal variations and qualitative modifications of the bivalve fauna composition in the framework of current biological pressures.

\section{MATERIALS AND METHODS}

\section{Study area}

Lebanon is an area of particular significance for the study of marine biodiversity and its recent changes. Lying at the north-eastern tip of the Mediterranean Sea, $450 \mathrm{~km}$ north of the Suez Canal, it is located along the natural pathways of Indo-Pacific taxa spreading from the Red Sea via the prevailing Mediterranean currents (Bergamasco \& Malanotte-Rizzoli 2010). Although the main coastal features and the respective communities are similar to those observed along all the Mediterranean shores (Bitar et al. 2007, Bitar 2010), several major engineering species are lacking, such as the seagrass Posidonia oceanica (Linnaeus) Delile, 1813 and the sea fans Paramuricea clavata (Risso, 1826) and Eunicella spp. (Harmelin et al. 2009).

\section{Bibliographic data}

An extensive literature survey was conducted using the same methods as Crocetta et al. (2013). Indexed papers were searched, but an attempt to cover the grey literature as much as possible (i.e. non-peerreviewed and/or non-indexed papers) was also per- 
formed. Most of the historical journals are not indexed, and many malacological records are still being published in non-indexed journals, thus allowing only manual searching. In addition, the availability of all historical taxon names based on Lebanese type material was checked.

\section{Sampling}

In order to evaluate the current molluscan fauna, the taxonomic composition was the main target of interest. Several sampling localities, covering more or less all of the Lebanese shores, were investigated by 2 of the authors (G. Bitar and H. Zibrowius) between 1999 and 2002 within the framework of the FrenchLebanese Programme CEDRE (see Zibrowius \& Bitar 2003, Morri et al. 2009). This material was later enriched by additional samples provided by one of the authors (G. Bitar) since 1988. Bivalves were found at 24 sites, with original samples spanning more than 20 yr (Table 1, Fig. 1, see Supplement at www.intres.com/articles/suppl/b019p075_supp.pdf). Sampling was carried out by snorkelling and SCUBA diving, during daylight hours only, and included different sampling techniques covering highly diversified habitats and approximately all the different accessible biotopes from the intertidal down to a depth of ca. $40 \mathrm{~m}$ (e.g. different types of hard and soft substrates, shady overhangs, Cymodocea and Halophila patches and meadows, caves, harbours, calcareous crusts including scleractinians, serpulids and bryozoans, Spondylus and Chama facies, infauna of coarse sand or mud) (Table 1, Supplement). The immediate visual recognition of key habitats and organisms was supplemented by underwater photography. When the number of observed individuals was particularly large, most of the largest or more abundant molluscs were released or not sampled after field identification to minimize the impact on the local biota.

\section{Laboratory work and updated taxonomy and nomenclature}

Upon arrival at the laboratory, samples were either dry preserved after removing the soft parts or fixed in $2 \%$ buffered formaldehyde and then transferred to $100 \%$ EtOH. They are currently preserved at the Dipartimento di Biologia e Biotecnologie 'Charles Darwin', La Sapienza University (Rome, Italy). Very worn specimens were discarded to exclude taphocoenotic contamination as much as possible. Identifi-
Table 1. Localities where bivalve species were found, with coordinates and depth ranges (see also Fig. 1). Details of biotopes from which the collections were made are reported in the Supplement under each species

\begin{tabular}{|llccc|}
\hline No. & Site & $\begin{array}{c}\text { Latitude } \\
\left({ }^{\circ}\right)\end{array}$ & $\begin{array}{c}\text { Longitude } \\
\left({ }^{\circ} \mathrm{E}\right)\end{array}$ & $\begin{array}{c}\text { Depth } \\
(\mathrm{m})\end{array}$ \\
\hline & & $3^{\circ}$ & \\
1 & Ramkine Island & $34^{\circ} 29^{\prime} 47^{\prime \prime}$ & $35^{\circ} 45^{\prime} 38^{\prime \prime}$ & $0-15$ \\
2 & Tripoli & $34^{\circ} 27^{\prime} 28^{\prime \prime}$ & $35^{\circ} 49^{\prime} 34^{\prime \prime}$ & $0-5$ \\
3 & Anfeh & $34^{\circ} 21^{\prime} 43^{\prime \prime}$ & $35^{\circ} 43^{\prime} 36^{\prime \prime}$ & $10-24$ \\
4 & Chekka & $34^{\circ} 19^{\prime} 12^{\prime \prime}$ & $35^{\circ} 43^{\prime} 14^{\prime \prime}$ & $3-6$ \\
5 & El Heri & $34^{\circ} 18^{\prime} 37^{\prime \prime}$ & $35^{\circ} 41^{\prime} 51^{\prime \prime}$ & $1-5$ \\
6 & Ras El Chakaa & $34^{\circ} 18^{\prime} 47^{\prime \prime}$ & $35^{\circ} 40^{\prime} 59^{\prime \prime}$ & $0-20$ \\
7 & Chak El Hatab & $34^{\circ} 17^{\prime} 36^{\prime \prime}$ & $35^{\circ} 40^{\prime} 17^{\prime \prime}$ & $9-14$ \\
8 & Selaata & $34^{\circ} 17^{\prime} 03^{\prime \prime}$ & $35^{\circ} 39^{\prime} 31^{\prime \prime}$ & $0-35$ \\
9 & Batrou & $34^{\circ} 15^{\prime} 13^{\prime \prime}$ & $35^{\circ} 39^{\prime} 19^{\prime \prime}$ & $2-9$ \\
10 & Kfar Abida & $34^{\circ} 14^{\prime} 02^{\prime \prime}$ & $35^{\circ} 39^{\prime} 15^{\prime \prime}$ & $1-12$ \\
11 & El Barbara & $34^{\circ} 11^{\prime} 32^{\prime \prime}$ & $35^{\circ} 37^{\prime} 19^{\prime \prime}$ & $26-28$ \\
12 & Jbail & $34^{\circ} 07^{\prime} 18^{\prime \prime}$ & $35^{\circ} 38^{\prime} 28^{\prime \prime}$ & $1-17$ \\
13 & Tabarja & $34^{\circ} 01^{\prime} 55^{\prime \prime}$ & $35^{\circ} 37^{\prime} 26^{\prime \prime}$ & $0-25$ \\
14 & Aquamarina & $34^{\circ} 00^{\prime} 51^{\prime \prime}$ & $35^{\circ} 37^{\prime} 57^{\prime \prime}$ & $10-25$ \\
15 & Beirut & $33^{\circ} 54^{\prime} 55^{\prime \prime}$ & $35^{\circ} 31^{\prime} 57^{\prime \prime}$ & $0-34$ \\
16 & Raoucheh & $33^{\circ} 53^{\prime} 18^{\prime \prime}$ & $35^{\circ} 28^{\prime} 01^{\prime \prime}$ & $7-10$ \\
17 & Khaldeh & $33^{\circ} 46^{\prime} 44^{\prime \prime}$ & $35^{\circ} 28^{\prime} 10^{\prime \prime}$ & 0 \\
18 & Saadiyat & $33^{\circ} 41^{\prime} 49^{\prime \prime}$ & $35^{\circ} 25^{\prime} 54^{\prime \prime}$ & 0 \\
19 & Saida & $33^{\circ} 34^{\prime} 00^{\prime \prime}$ & $35^{\circ} 22^{\prime} 10^{\prime \prime}$ & $10-31$ \\
20 & El Zahrani & $33^{\circ} 29^{\prime} 46^{\prime \prime}$ & $35^{\circ} 20^{\prime} 01^{\prime \prime}$ & $11-24$ \\
21 & El Kassmieh & $33^{\circ} 20^{\prime} 22^{\prime \prime}$ & $35^{\circ} 14^{\prime} 19^{\prime \prime}$ & $42-44$ \\
22 & Tyr & $33^{\circ} 15^{\prime} 56^{\prime \prime}$ & $35^{\circ} 11^{\prime} 24^{\prime \prime}$ & $0-15$ \\
23 & El Bayada & $33^{\circ} 09^{\prime} 96^{\prime \prime}$ & $35^{\circ} 10^{\prime} 85^{\prime \prime}$ & $3-5$ \\
24 & Nakoura & $33^{\circ} 06^{\prime} 57^{\prime \prime}$ & $35^{\circ} 07^{\prime} 11^{\prime \prime}$ & $3-5$ \\
& & & & \\
\hline & & & & \\
\hline
\end{tabular}

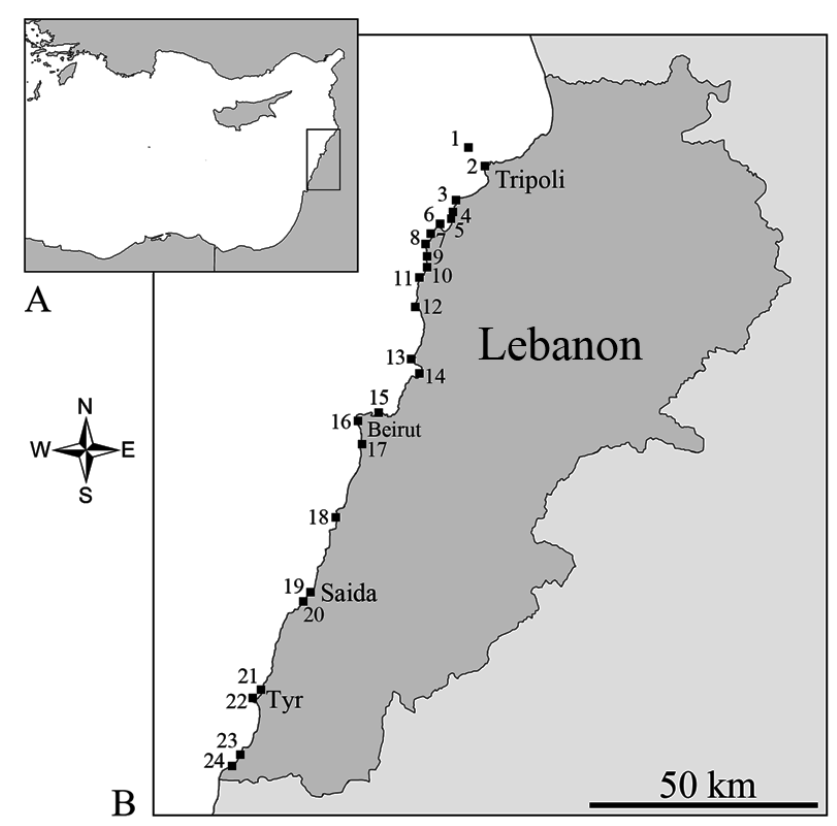

Fig. 1. Study area. (A) The eastern Mediterranean Sea. (B) Sampling sites. Numbers as in Table 1 
cations were carried out by the first author (F. Crocetta) to species level, when possible, according to the most recent bivalve guides (Oliver 1992, Zenetos et al. 2004, Huber 2010, Gofas et al. 2011), as well as modern specialist papers (see Supplement). Updated taxonomy and nomenclature follow the World Register of Marine Species (WoRMS; www.marinespecies. org/, last accessed 16 June 2013) with a few exceptions (taxa listed as a still unsolved complex, if current knowledge does not allow correct identification of taxa from the morphology/anatomy alone, and new synonymies proposed). The authorities of the molluscan species listed below are mostly only reported in the Supplement.

\section{Comparisons between past and modern bivalve fauna}

Bibliographic data were re-analysed and taxonomically adjusted to allow comparisons. Most of the typical Mediterranean species are taxa clearly recognized by malacologists for centuries, thus suggesting that their presence/absence cannot have gone unnoticed. Using the bibliographic data available, the past (before 1950) and modern (after 1950) bivalve faunal lists were qualitatively compared. Special emphasis was given to alien species, for each of which the following data are provided: published and unpublished records from the coastal and offshore territorial seawaters of Lebanon, date of first record, most plausible vector(s) of introduction and establishment status, mostly following the terminology used in Crocetta (2012).

\section{RESULTS}

An updated checklist of 114 taxa of bivalves recorded in Lebanon, including bibliographic records and original data from field samplings, is reported in Table 2 (96 native species: ca. $84 \%$ ) and Table 3 (18 alien species: ca. $16 \%$ ). Full details are reported in the Supplement at www.int-res.com/articles/suppl/ b019p075_supp.pdf. The obtained faunal data were divided into the 2 main periods (past: before 1950, and modern: after 1950) to allow comparisons and trace temporal variations and qualitative modifications of the local bivalve fauna.

\section{Before 1950: past molluscan assemblage}

The 79 taxa reported as occurring along the Lebanese shores before 1950 are listed in Tables 2 \& 3 (see also Supplement). Among them, 21 bivalve taxa have been historically described based on Lebanese material, and their current status is reported in Table 4. Eleven of them are nomina nuda (ICZN 1999: Art. 12), 8 have infrasubspecific rank and thus are not available (ICZN 1999: Art. 45.5, 45.6), whilst Ostrea stentina var. syriaca and Syndosmia cottardi var. orientalis are available, having evidently being instituted as geographic races and thus are of subspecific rank. They are here considered as synonyms of Ostrea stentina and Scrobicularia cottardi, based on the available type material (Muséum National d'Histoire Naturelle: MNHN-25215) and the original figure (see Pallary 1938, his Fig. 17, Plate II), respectively. The 75 native species (ca. 95\%) (Table 2) mainly comprised well-known macrobenthic taxa. There were only 4 alien species (ca. $5 \%$ ) (Table 3, Fig. 2A): Brachidontes pharaonis, Pinctada imbricata radiata, Malleus regula and Mactra olorina.

\section{After 1950: modern molluscan assemblage}

The modern records of 38 taxa were traced in the literature (Tables $2 \& 3$ ). Their critical re-assessment, together with the analysis of material obtained from field samplings (1032 complete specimens and 1045 loose valves) provided additional records of 74 taxa (Tables 2 \& 3). Fifteen native (Musculus subpictus, Limatula cfr. gwyni, Lucinella divaricata, Megaxinus unguiculinus, Bornia geoffroyi, Kurtiella bidentata, Coripia corbis, Coripia jozinae, Digitaria digitaria, Gonilia calliglypta, Parvicardium scriptum, Spisula subtruncata, Arcopella balaustina, Hiatella arctica and Thracia phaseolina) and 9 alien (Lioberus ligneus, Spondylus sp., Dendostrea folium, Chama asperella, Afrocardium richardi, Fulvia fragilis, Mactra lilacea, Petricola fabagella and Sphenia rueppellii) taxa were first recorded in Lebanon, with a total of 67 native (ca. $80 \%$ ) and 17 alien (ca. $20 \%$ ) species reported after 1950 (Fig. 2A). Among them, 2 species deserve attention (Fig. 3). Lioberus ligneus, widespread in the South African and Indo-Pacific provinces, including the Red Sea (Oliver 1992, Huber 2010), is recorded here for the first time in the Mediterranean, based on 7 loose valves and 1 complete specimen sampled in 2 different localities in 1999 and 2000 (Sites 1 and 19, see Supplement). Distinctive shell features with respect to the congeneric $L$. agglutinans are the weaker umbones and the less tumid shape, which is more expanded dorsally. Notably, the specimen recorded in Egypt by Pallary (1912b) as Modiola agglutinans Cantraine 


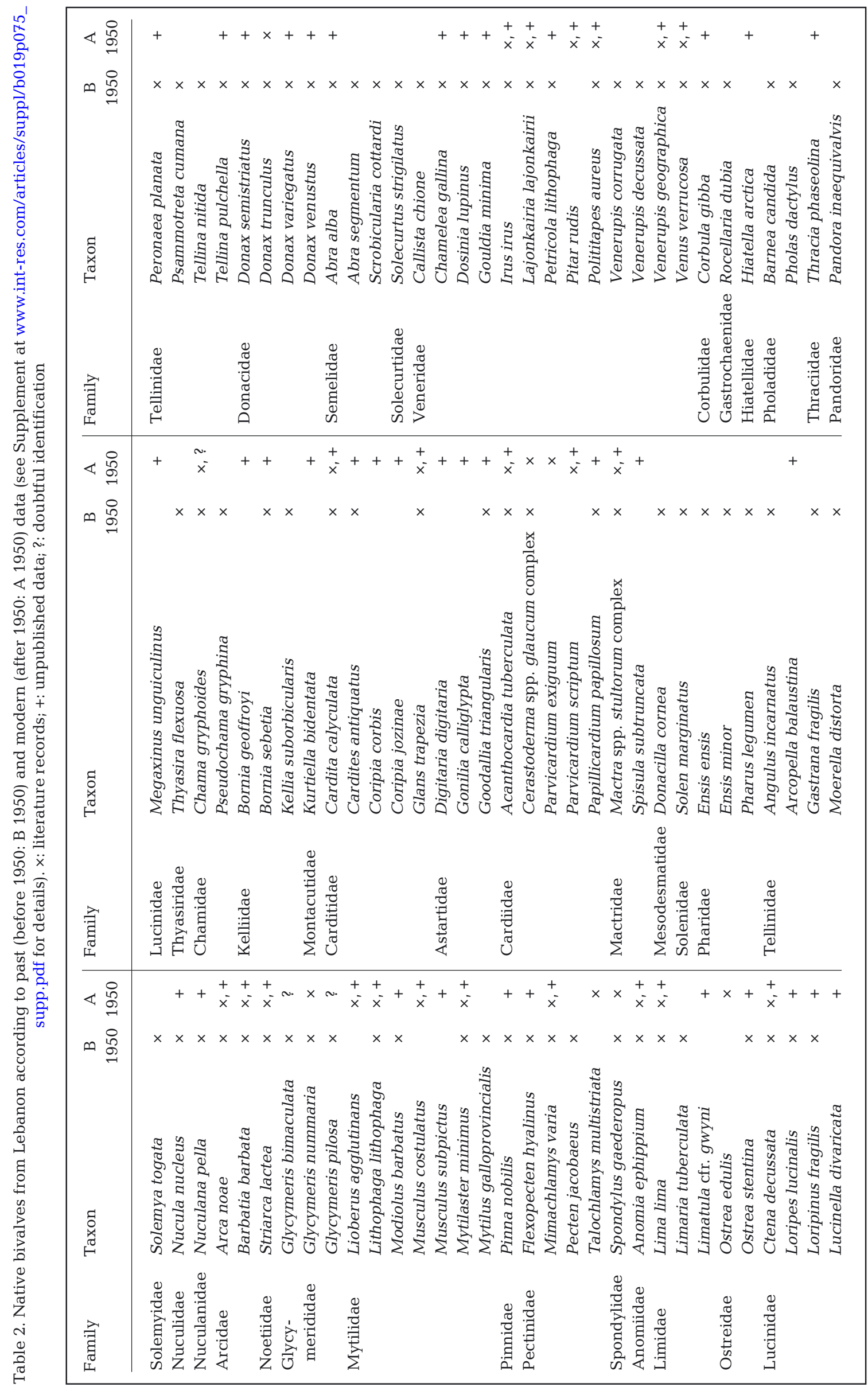


Table 3. Alien bivalves from Lebanon according to past (before 1950: B 1950) and modern (after 1950: A 1950) data, with first record dates (FRD), plausible vectors of introduction along the Lebanese shores (V) and known establishment status (ES) (see Supplement for details). x: literature records; +: unpublished data; AS: alien spreading via Suez Canal; U: unknown; E: established; C: casual

\begin{tabular}{|c|c|c|c|c|c|c|}
\hline Family & Taxon & $\begin{array}{c}\text { B } \\
1950\end{array}$ & $\begin{array}{c}\text { A } \\
1950\end{array}$ & FRD & $\mathrm{V}$ & ES \\
\hline Arcidae & Anadara natalensis & & $x$ & 1992 (present study) & AS & $\mathrm{C}$ \\
\hline \multirow[t]{2}{*}{ Mytilidae } & Brachidontes pharaonis & $x$ & $x_{1}+$ & before 1929 (Gruvel \& Moazzo 1929) & AS & $\mathrm{E}$ \\
\hline & Lioberus ligneus & & + & 1999 (present study) & AS & $\mathrm{C}$ \\
\hline Pteriidae & Pinctada imbricata radiata & $x$ & $x_{1}+$ & before 1911 (Pallary 1911) & AS & $\mathrm{E}$ \\
\hline Malleidae & Malleus regula & $x$ & $x_{1}+$ & 1929-1930 (Pallary 1938) & AS & $\mathrm{E}$ \\
\hline \multirow[t]{2}{*}{ Spondylidae } & Spondylus spinosus & & $x_{1}+$ & 1999 (present study) & AS & E \\
\hline & Spondylus sp. & & + & 2003 (present study) & $\mathrm{U}$ & $\mathrm{C}$ \\
\hline Ostreidae & Dendostrea folium & & + & 2012 (present study) & AS & $\mathrm{E}$ \\
\hline \multirow[t]{2}{*}{ Chamidae } & Chama asperella & & + & 1999 (present study) & AS & $\mathrm{C}$ \\
\hline & Chama pacifica & & $x_{1}+$ & 1999 (Crocetta \& Russo 2013) & AS & $\mathrm{E}$ \\
\hline \multirow[t]{2}{*}{ Cardiidae } & Afrocardium richardi & & + & 1999 (present study) & AS & $\mathrm{C}$ \\
\hline & Fulvia fragilis & & + & 2003 (present study) & AS & $\mathrm{E}$ \\
\hline \multirow[t]{2}{*}{ Mactridae } & Mactra lilacea & & + & 2002 (present study) & AS & $\mathrm{C}$ \\
\hline & Mactra olorina & $x$ & & before 1929 (Gruvel \& Moazzo 1929) & AS & $\mathrm{C}$ \\
\hline \multirow[t]{2}{*}{ Veneridae } & Gafrarium savignyi & & $x_{1}+$ & before 1998 (Bitar \& Kouli-Bitar 1998) & AS & $\mathrm{E}$ \\
\hline & Petricola fabagella & & + & 2000 (present study) & AS & $\mathrm{C}$ \\
\hline Myidae & Sphenia rueppellii & & + & 2000 (present study) & AS & $\mathrm{C}$ \\
\hline Laternulidae & Laternula anatina & & $x$ & before 1987 (Bogi \& Khairallah 1987) & AS & $\mathrm{C}$ \\
\hline
\end{tabular}

(his Table XVIII, Figs. 36 \& 37 only) presumably belongs to the same species. Conversely, the identification of Spondylus sp. is somehow puzzling. It

Table 4. Bivalve nominal taxa historically described on type material from Lebanon, arranged in systematic order (see Supplement for details). nn: nomen nudum; inf: infrasubspecific rank; a: available

\begin{tabular}{|llc|}
\hline Author & Proposed taxon & Status \\
\hline Pallary (1938) & Pectunculus violacescens var. alba & $n n$ \\
Pallary (1919) & Modiola barbata var. minor & $n n$ \\
Pallary 1919) & Pinna nobilis var. nana & inf \\
Pallary (1912a) & Meleagrina occa var. minor & inf \\
Pallary (1938) & Meleagrina albina var. minor & inf \\
Pallary (1938) & Malleus regula var. minor & inf \\
Pallary (1933) & Ostrea stentina syriaca & $n n$ \\
Pallary (1938) & Ostrea stentina var. syriaca & a \\
Pallary (1938) & Jagonia decussata var. parva & inf \\
Pallary (1938) & Kellya sebetia var. minor & inf \\
Pallary (1938) & Cardita calyculata var. major & inf \\
Puton (1856) & Mactra stultorum var. compressa & $n n$ \\
Pallary (1938) & Mactra corallina var. trigona & inf \\
Pallary (1938) & Fragilia fragilis var. syriaca & $n n$ \\
Pallary (1938) & Donax semistriata sous-var. minor & $n n$ \\
Pallary (1938) & Donax trunculus var. minor & $n n$ \\
Pallary (1933) & Syndesmia cottardi orientalis & $n n$ \\
Pallary (1938) & Syndosmia cottardi var. orientalis & a \\
Pallary (1938) & Tapes aureus var. minor & $n n$ \\
Pallary (1912a) & Tapes geographicus var. minor alba & $n n$ \\
Pallary (1938) & Corbula gibba var. minor & $n n$ \\
& & \\
\hline
\end{tabular}

may belong to Spondylus nicobaricus Schreibers, 1793 (M. Huber pers. comm.), but we prefer to keep it here as unidentified, pending more detailed analysis and further specimens.

\section{Special emphasis on alien species}

The combined literature-material approach provided a list of 20 alien species in Lebanon (see Table 3 and Supplement for details), but the presence of 2 of them (Spondylus groschi Lamprell \& Kilburn, 1995 and Spondylus cf. multisetosus Reeve, 1856) is excluded here as this was based on 1 specimen and on a worn loose valve that falls within the variability of Spondylus spinosus (see Supplement). Ca. $95 \%$ of the alien species in Lebanese waters are Erythraean species, and this value will rise to $100 \%$ if the tentative identification of Spondylus sp. as S. nicobaricus Schreibers, 1793 is confirmed (Table 3). However, only 8 of them were here considered established, while the remaining 10 taxa are currently known on the basis of a few sporadic specimens and are therefore considered casual (Table 3, Supplement). Further field studies may confirm their local establishment or, possibly, their ephemeral presence. The rate at which first records of alien molluscan species were reported, estimated per decade, is listed in Table 3 and plotted in Fig. 2B. 

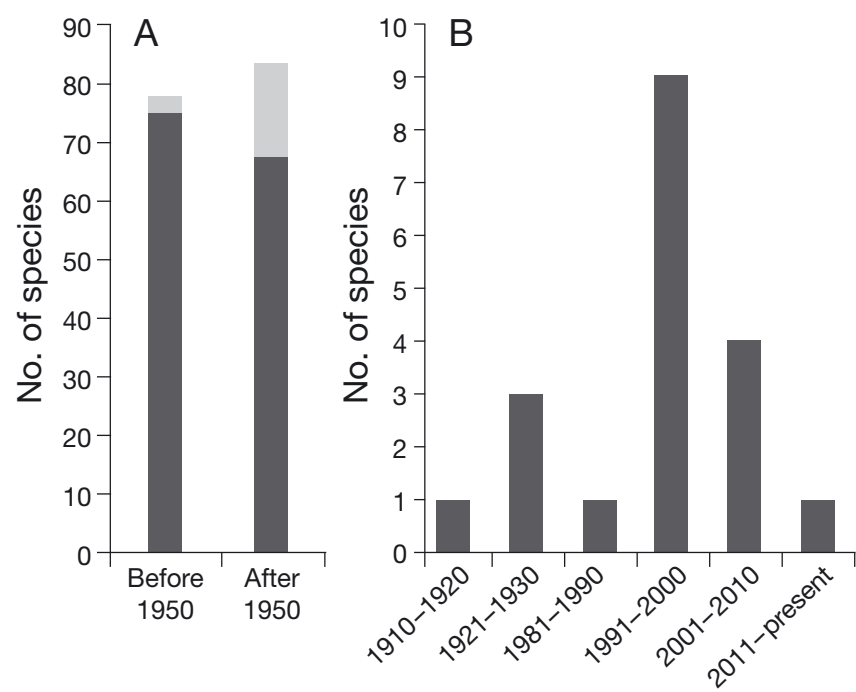

Fig. 2. (A) Past (before 1950) and modern (after 1950) native (dark grey) and alien (light grey) Lebanese bivalve fauna. (B) Rate of first reports of alien molluscan species in Lebanon. The 1931-1980 gap is due to the lack of records (see 'Introduction'). See Tables $2 \& 3$ for details

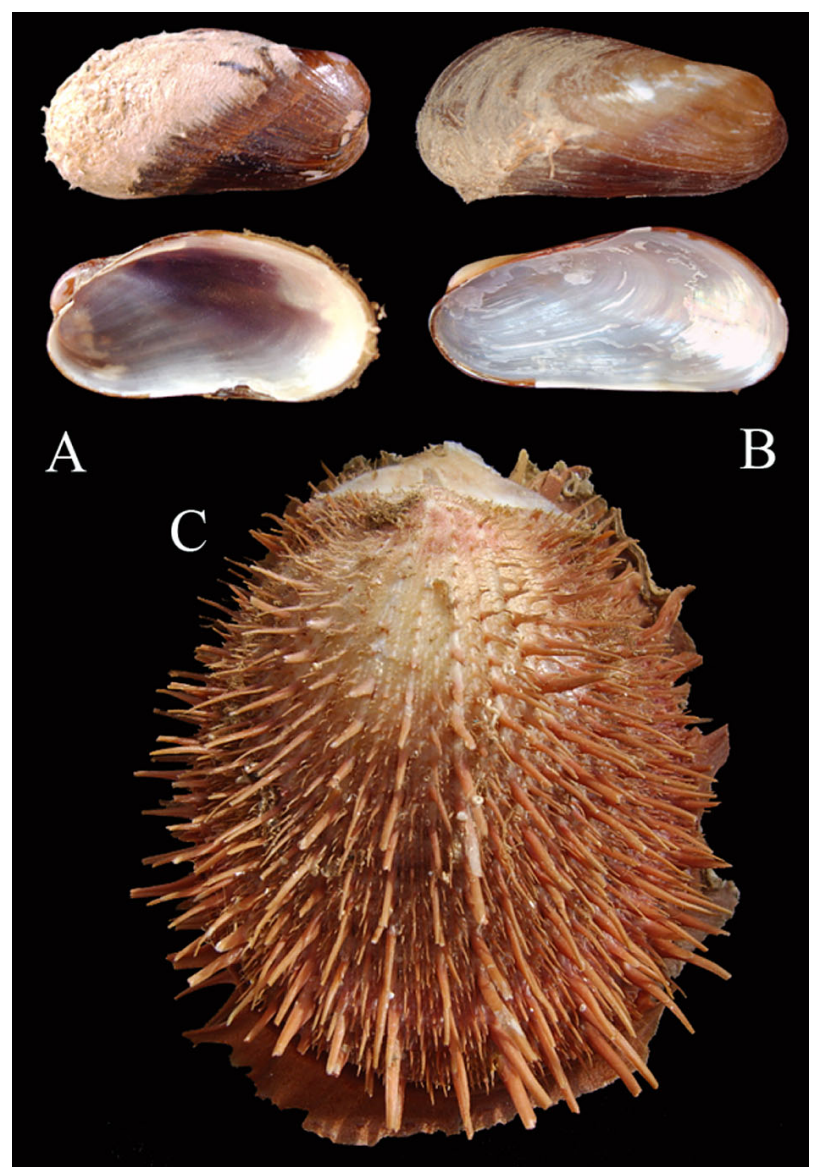

Fig. 3. Bivalves from Lebanon (not to scale, sizes reported as maximum height $\times$ maximum width). (A) Lioberus agglutinans (Cantraine, 1835), $16 \times 31 \mathrm{~mm}$. (B) Lioberus ligneus (Reeve, 1858), $17 \times 35 \mathrm{~mm}$. (C) Spondylus sp., $72 \times 60 \mathrm{~mm}$

\section{DISCUSSION}

Bivalves are an important component of benthic marine ecosystems and constitute the second most diverse class of Mollusca after gastropods. Many of them are well studied, not only as biodiversity components (Giacobbe 2002, Rabaoui et al. 2009) or indicators of ecosystem instability (Occhipinti-Ambrogi et al. 2005, Nerlovi et al. 2011), but because they often serve as pollution indicators (Morcillo et al. 1999) or are commercially exploited (Voultsiadou et al. 2010, Katsanevakis et al. 2011). So far, ca. 400 native bivalve species and less than 100 alien bivalve species have been recorded in the Mediterranean Sea (Coll et al. 2010, Zenetos et al. 2012). However, considering the continuous description of new species in the Mediterranean (more than 100 molluscs during the last $10 \mathrm{yr}$ alone, Crocetta et al. 2012), the unexpected results obtained by the combined use of molecular and morphological approaches (Calvo et al. 2009, Guarniero et al. 2010), and the increasing trend of colonization of the Mediterranean Sea by alien species (Galil 2009, Zenetos et al. 2012), these figures are deemed to increase in the near future.

The 114 Lebanese species listed here belong to 39 families and 87 genera. The richest family is Veneridae Rafinesque, 1815 with 15 species (ca. 13\%), followed by Mytilidae Rafinesque, 1815 with 9 species (ca. $8 \%$ ) and Tellinidae Blainville, 1814 with 8 species (ca. $7 \%$ ). The genus Donax Linnaeus, 1758 is the most diverse, with 4 species (ca. $3.5 \%$ ). This still represents a particularly poor fauna, accounting for ca. $26.5 \%$ of the native and alien Mediterranean bivalve species (Coll et al. 2010). Even if the absence of several common species with Atlantic-Mediterranean distribution and of Mediterranean endemics from the Lebanese and, more generally, the eastern Mediterranean fauna may be plausible, the possibility that the very low bivalve biodiversity recorded here is at least partially an underestimation should not be dismissed. The deep waters of the Levant basin have not been intensively explored (Bogi \& Galil 2004, 2013, Galil 2004), and the Lebanese area, in particular, has not been sampled deeper than $\sim 40 \mathrm{~m}$. Therefore, these data clearly suggest that thorough investigations are still needed for a better understanding of the whole eastern Mediterranean fauna. However, the 24 new records reported here, including the first record of Lioberus ligneus in the Mediterranean Sea, highlight the importance of continuous field sampling in filling geographic gaps.

Admittedly, our Lebanon data are based on a sampling methodology not specifically aimed at this group of molluscs, since our new material, in particu- 
lar, originates from general sampling of benthic marine species and communities. Therefore, many tiny and cryptic species might have been overlooked, and the lack of specific surveys focused on this class may have prevented an exhaustive work. Notwithstanding the limitations of these qualitative samples, some interesting conclusions may be drawn. In fact, when comparing faunal data obtained during the past and modern periods of investigation, 2 issues were raised. On the one side, an increase in local biodiversity may be perceived, with 79 taxa recorded before 1950 and 84 after 1950 (Fig. 2A). On the other side, remarkable local shifts in faunal composition, previously suggested for the eastern Mediterranean shores on the basis of visual assessments only (Mienis 2003, Galil 2007, Bitar 2010), were here demonstrated with sound data. In fact, even if the new records of native species mainly concerned small-sized species, and may be presumably attributed to an incomplete previous investigation, the scarcity (or total absence) in our most recent samples of once common native habitatforming species such as Mytilus galloprovincialis, Mytilaster spp., Spondylus gaederopus and Chama gryphoides, along with some other native taxa, would suggest their recent rarefaction (or local extinction), possibly related to their replacement by the aliens Brachidontes pharaonis, Spondylus spinosus and Chama pacifica. In addition, the wide beds of these habitat-forming alien species observed during our study suggest an establishment for a relatively long time. However, the rate of recording of new alien species (evaluated on decades) revealed an absence of records prior to 1900 (see Puton 1856) and only sporadic findings in 1911 to 1930 (see Pallary 1911, 1912a, 1919, 1933, 1938, Gruvel \& Moazzo 1929, Gruvel 1931, Moazzo 1931) (Table 3, Fig. 2B), with only 4 alien species (ca. $5 \%$ of the past species, ca. $3.5 \%$ of the total historical list) recorded within the past molluscan biota. The well-known alien species recorded early in Lebanon (Brachidontes pharaonis, Pinctada imbricata radiata, Malleus regula and Mactra olorina) are indeed among the first Mediterranean colonizers (see review in Zenetos et al. 2004), and thus an early presence along the Lebanese shores is not surprising (Table 3, Fig. 2A). Conversely, 17 alien species (ca. $20 \%$ of the modern species, ca. $15 \%$ of the total historical list) are recorded within the modern molluscan biota, a proportion within the range of 10 to $20 \%$ commonly estimated for the entire Levantine fauna (Zenetos et al. 2010). Higher proportions $(\sim 34 \%)$ have been previously noted for other molluscan groups (Crocetta et al. 2013), but the strong morphological resemblance among some
Mediterranean and Red Sea species suggests that a final assessment of these figures will require the use of molecular data to confirm the identifications of taxonomically difficult species, including cryptogenics. Finally, although the peak in records in conjunction with our field work (1991 to 2010) is obviously due to the increased sampling, our data clearly show a late alien species arrival into Lebanon, especially when compared with other eastern Mediterranean countries such as Egypt and Israel (Zenetos et al. 2004, Galil 2007). This is paralleled by a similar pattern noted for other unmistakable macrobenthic alien bivalve taxa (e.g. Chama pacifica, Fulvia fragilis and Gafrarium savignyi $[=G$. pectinatum sensu auct.]), whose first Mediterranean records date back to the beginning of the 20th century (Tillier \& Bavay 1905, Moazzo 1939) but whose definitive spreading only occurred decades later. A plausible hypothesis is that this is related to the recent temperature increase in the Mediterranean, which has made it, first the eastern basin, and thereafter the entire Mediterranean, progressively more suitable for biological invasion by tropical species (Oliverio \& Taviani 2003).

Acknowledgements. S. Albayrak (Istanbul), B. Galil (Haifa), S. Gofas (Malaga), H. K. Mienis (Tel-Aviv), B. Öztürk (Izmir), W. Renda (Amantea) and P. Russo (Venice) offered bibliographic support and comments on several topics. G. Fasulo (Naples) provided material for comparison. P. Maestrati and V. Héros (Paris) provided information on type specimens. M. Huber (Zürich) discussed the identifications of Lioberus spp., Spondylus sp., Ostreola stentina and Petricola spp., and made detailed comments on several species. Two further reviewers provided very constructive criticisms of the manuscript. We are grateful to all of them. Research was partially supported by the Programme CEDRE - coopération franco libanaise (1999-2002) (R 2000 Eb F 42/L43) (H.Z. and G.B.).

\section{LITERATURE CITED}

Bariche M (2012) Field identification guide to the living marine resources of the eastern and southern Mediterranean. FAO species identification guide for fishery purposes. Food and Agriculture Organization of the United Nations, Rome, Italy

Bergamasco A, Malanotte-Rizzoli P (2010) The circulation of the Mediterranean Sea: a historical review of experimental investigations. Adv Oceanogr Limnol 1:11-28

Bianchi CN (2007) Biodiversity issues for the forthcoming tropical Mediterranean Sea. Hydrobiologia 580:7-21

- Bianchi CN, Morri C (2000) Marine biodiversity of the Mediterranean Sea: situation, problems and prospects for future research. Mar Pollut Bull 40:367-376

Bitar G (1996) Le macrozoobenthos. In: Minist Agr Liban (Ed) Etude de la biodiversité biologique du Liban. Publ. Faune et flore marines et côtières, PNUE, Projet GF/ 6105-92-72, p 41-48, 113-126 
Bitar G (2010) Impact des changements climatiques et des especes exotiques sur la biodiversite et les habitats marins au Liban. Rapp Comm Int Mer Médit 39:452

Bitar G (2013) Les mollusques exotiques de la côte libanaise. 3éme Congres Franco-Maghrebin de Zoologie et d'Ichtyologie, Marrakech 2012, p 8

Bitar G, Kouli-Bitar S (1995a) Apercu de bionomie benthique et répartition des différents faciès de la roche littorale à Hannouch (Liban-Méditerranée Orientale). Rapp Comm Int Mer Médit 34:19

Bitar G, Kouli-Bitar S (1995b) Impact de la pollution sur la répartition des peuplements de substrat dur à Beyrouth (Liban-Méditerranée Orientale). Rapp Comm Int Mer Médit 34:19

Bitar G, Kouli-Bitar S (1998) Inventaire des mollusques marines benthiques du Liban et remarques biogéographiques sur quelques espèces nouvellement signalés. Mesogée 56:37-44

Bitar G, Kouli-Bitar S (2001) Nouvelles donnees sur la faune et la flore benthiques de la cote libanaise. Migration Lessepsienne. Thalassia Salentina 25:71-74

Bitar G, Ocaña O, Ramos-Esplà A (2007) Contribution of the Red Sea alien species to structuring some benthic biocenosis in the Lebanon coast (Eastern Mediterranean). Rapp Comm Int Mer Médit 38:437

Bogi C, Galil BS (2004) The bathybenthic and pelagic molluscan fauna off the Levantine coast, eastern Mediterranean. Boll Malacol 39:79-90

Bogi C, Galil BS (2013) New molluscan records from the eastern Mediterranean bathyal. Mar Biodiversity Rec 6:e19

Bogi C, Khairallah NH (1987) Nota su alcuni molluschi de provenienza Indo-Pacifica raccolti nella baia di Jounieh (Libano)-Contributo I. Notiziario del CISMA 10:54-60

Brusina MS (1879) Chapitre V. Les escales des Messageries maritimes dans le Levant. In: De Folin L, Périer L (eds) Les fonds de la Mer. Tome troisieme. Savy, LibraireÉditeur, Paris, p 25-32

Calvo M, Templado J, Oliverio M, Machordom A (2009) Hidden Mediterranean biodiversity: molecular evidence for a cryptic species complex within the reef building gastropod Dendropoma petraeum (Mollusca: Caenogastropoda). Biol J Linn Soc 96:898-912

Coll M, Piroddi C, Steenbeek J, Kaschner K and others (2010) The biodiversity of the Mediterranean Sea: estimates, patterns, and threats. PLoS ONE 5:e11842

Crocetta F (2012) Marine alien Mollusca in Italy: a critical review and state of the knowledge. J Mar Biol Ass UK 92:1357-1365

Crocetta F, Russo P (2013) The alien spreading of Chama pacifica Broderip, 1835 (Mollusca: Bivalvia: Chamidae) in the Mediterranean Sea. Turk J Zool 37:92-96

Crocetta F, Bonomolo G, Albano PG, Barco A, Houart R, Oliverio M (2012) The status of the northeastern Atlantic and Mediterranean small mussel drills of the Ocinebrina aciculata complex (Mollusca: Gastropoda: Muricidae), with the description of a new species. Sci Mar 76: 177-189

Crocetta F, Zibrowius H, Bitar G, Templado J, Oliverio M (2013) Biogeographical homogeneity in the eastern Mediterranean Sea - I: the opisthobranchs (Mollusca: Gastropoda) from Lebanon. Medit Mar Sci 14:403-408.

Fadlallah YH (1975) Systematics and ecology of benthic macroinvertebrates in the eastern Mediterranean. MSc dissertation, American University of Beirut
Galil BS (2004) The limit of the sea: the bathyal fauna of the Levantine Sea. Sci Mar 68:63-72

Galil BS (2007) Seeing red: alien species along the Mediterranean coast of Israel. Aquat Invas 2:281-312

> Galil BS (2009) Taking stock: inventory of alien species in the Mediterranean Sea. Biol Invas 11:359-372

> Giacobbe S (2002) Epibiontic mollusc communities on Pinna nobilis L. (Bivalvia, Mollusca). J Nat Hist 36:1385-1396

Gofas S, Moreno D, Salas C (2011) Moluscos marinos de Andalucía - II. Servicio de Publicaciones e Intercambio Científico, Universidad de Málaga

Gruvel A (1931) F. Mollusques. In: Gruvel A (ed) Les Etats de Syrie. Richesses marines et fluviales, exportation actuelle. Avenir. Société d'Edition Geographiques, Maritimes et Coloniales, Paris, p 122-127

Gruvel A, Moazzo G (1929) Première liste de mollusques récoltés par MM. A. Gruvel et G. Moazzo sur les côtes de Syrie. Bull Mus Natn Hist Nat 1:419-429

Guarniero I, Plazzi F, Bonfitto A, Rinaldi A, Trentini M, Passamonti M (2010) The bivalve mollusc Mactra corallina: genetic evidence of existing sibling species. J Mar Biol Ass UK 90:633-644

> Harmelin JG, Bitar G, Zibrowius H (2009) Smittinidae (Bryozoa, Cheilostomata) from coastal habitats of Lebanon (Mediterranean sea), including new and non-indigenous species. Zoosystema 31:163-187

Huber M (2010) Compendium of bivalves. A full-color guide to 3300 of the world's marine bivalves. A status on Bivalvia after 250 years of research. ConchBooks, Hackenheim

ICZN (International Commission on Zoological Nomenclature) (1999) International code of zoological nomenclature, 4th edn. International Trust for Zoological Nomenclature, London

Katsanevakis S, Poursanidis D, Issaris Y, Panou A and others (2011) 'Protected' marine shelled molluscs: thriving in Greek seafood restaurants. Medit Mar Sci 12:429-438

Lejeusne C, Chevaldonné P, Pergent-Martini C, Boudouresque $C$, Pérez $T$ (2010) Climate change effects on a miniature ocean: the highly diverse, highly impacted Mediterranean Sea. Trends Ecol Evol 25:250-260

- Manzi V, Gennari R, Hilgen F, Krijgsman W, Lugli S, Roveri M, Sierro FJ (2013) Age refinement of the Messinian salinity crisis onset in the Mediterranean. Terra Nova 25: $315-322$

Mienis HK (2003) Native marine mollusks replaced by Lessepsian migrants. Tentacle 11:15-16

Moazzo G (1931) Contributo alla fauna malacologica marina delle coste libano siriane. In: Gruvel A (ed) Les Etats de Syrie. Richesses marines et fluviales, exportation actuelle. Avenir. Société d'Edition Geographiques, Maritimes et Coloniales, Paris, p 437-453

Moazzo PG (1939) Mollusques testacés marins du Canal de Suez. Mém Inst Egypte 38:1-283

Morcillo Y, Albalat A, Porte C (1999) Mussels as sentinels of organotin pollution: Bioaccumulation and effects on P450-mediated aromatase activity. Environ Toxicol Chem 18:1203-1208

Morri C, Puce S, Bianchi CN, Bitar G, Zibrowius $\mathrm{H}$, Bavestrello G (2009) Hydroids (Cnidaria: Hydrozoa) from the Levant Sea (mainly Lebanon), with emphasis on alien species. J Mar Biol Ass UK 89:49-62

Nakhlé KF, Cossa D, Khalaf G, Beliaeff B (2006) Brachidontes variabilis and Patella sp. as quantitative biological indicators for cadmium, lead and mercury in the Lebanese coastal waters. Environ Pollut 142:73-82 
Nerlović V, Doğan A, Hrs-Brenko M (2011) Response to oxygen deficiency (depletion): Bivalve assemblages as an indicator of ecosystem instability in the northern Adriatic Sea. Biologia 66:1114-1126

Occhipinti-Ambrogi A (2007) Global change and marine communities: alien species and climate change. Mar Pollut Bull 55:342-352

Occhipinti-Ambrogi A, Savini D, Forni G (2005) Macrobenthos community structural changes off Cesenatico coast (Emilia Romagna, Northern Adriatic), a six-year monitoring programme. Sci Total Environ 353:317-328

Oliver PG (1992) The bivalve seashells of the Red Sea. An identification guide. Christa Hemmen Verlag \& The National Museum of Wales, Cardiff

Oliverio M (2003) The Mediterranean molluscs: the best known malacofauna of the world: so far. Biogeographia 24:195-208

Oliverio M, Taviani M (2003) The Eastern Mediterranean Sea: tropical invasions and niche availability in a 'Godot Basin'. Biogeographia 24:313-318

Pallary P (1911) Sur la présence de la petite Pintadine de la Mar Rouge sur le côtes de la Syrie. Bull Soc Hist Nat Afr Nord 2:42

Pallary P (1912a) Liste des mollusques marins des cotes de la Syrie. La Feuille des jeunes naturalistes: revue mensuelle d'histoire naturelle 42:171-174

Pallary P (1912b) Catalogue des mollusques du littoral méditerranéen de d'Égypte. Mém Inst Egypte 7:69-207

Pallary P (1919) Enumération des mollusques marins des côtes de la Syrie (Suite et fin). Bull Soc Hist Nat Afr Nord 10:175-176

Pallary P (1933) Résultats généraux d'une prospection malacologique effectuée en Syrie de 1929 à 1932. Bull Mus Natn Hist Nat 5:148-154

Pallary P (1938) Les mollusques marins de la Syrie. J Conchyl 82:5-57

Philippart CJM, Anadón R, Danovaro R, Dippner JW and others (2011) Impact of climate change on European marine ecosystems: observations, expectations and indicators. J Exp Mar Biol Ecol 400:52-69

Por FD (1978) Lessepsian migrations: the influx of Red Sea biota into the Mediterranean by way of the Suez Canal. Ecological Studies 23. Springer, Heidelberg

Puton M (1856) Lettre au docteur Mougeot sur les Mollusques de Syrie, envoyés au musée des Vosges par M. le docteur Gaillardot. Ann Soc Emul Départ Vosges 9:

Editorial responsibility: Riccardo Cattaneo-Vietti, Ancona, Italy
219-231

Rabaoui L, Tlig-Zouari S, Cosentino A, Ben Hassine OK (2009) Associated fauna of the fan shell Pinna nobilis (Mollusca: Bivalvia) in the northern and eastern Tunisian coasts. Sci Mar 73:129-141

Raitsos DE, Beaugrand G, Georgopoulos D, Zenetos A, Pancucci-Papadopoulou M, Theocharis A, Papathanassiou E (2010) Global climate change amplifies the entry of tropical species into the Eastern Mediterranean Sea. Limnol Oceanogr 55:1478-1484

Sabelli B, Taviani M (in press) The making of the Mediterranean molluscan biodiversity. In: Goffredo S, Dubinsky $\mathrm{Z}$ (eds) The Mediterranean Sea: its history and present challenges. Springer, Dordrecht

Shiber JG (1980) Trace metals with seasonal considerations in coastal algae and molluscs from Beirut, Lebanon. Hydrobiologia 69:147-162

Shiber JG, Shatila TA (1978) Lead, cadmium, copper, nickel and iron in limpets, mussels and snails from the coast of Ras Beirut, Lebanon. Mar Environ Res 1:125-134

Spada G (1971) Ritrovamenti malacologici nelle acque di Beirut (Libano). Conchiglie 7:85-93

Tillier L, Bavay A (1905) Les mollusques testacés du Canal de Suez. Bull Soc Zool Fr 30:170-181

Voultsiadou E, Koutsoubas D, Achparaki M (2010) Bivalve mollusc exploitation in Mediterranean coastal communities: an historical approach. J Biol Res Thessaloniki 13: $35-45$

Zenetos A, Gofas S, Russo G, Templado J (2004) CIESM Atlas of exotic species in the Mediterranean, Vol 3 Molluscs. CIESM Publishers, Monaco

Zenetos A, Gofas S, Verlaque M, Çinar ME and others (2010) Alien species in the Mediterranean Sea by 2010. A contribution to the application of European Union's Marine Strategy Framework Directive (MSFD). Part I. Spatial distribution. Medit Mar Sci 11:381-493

Zenetos A, Gofas S, Morri C, Rosso A and others (2012) Alien species in the Mediterranean Sea by 2012. A contribution to the application of European Union's Marine Strategy Framework Directive (MSFD). Part 2. Introduction trends and pathways. Medit Mar Sci 13:328-352

Zibrowius H, Bitar G (1981) Serpulidae (Annelida Polychaeta) indo-pacifiques établis dans la région de Beyrouth, Liban. Rapp Comm Int Mer Médit 27:159-160

Zibrowius H, Bitar G (2003) Invertébrés marins exotiques sur la côte du Liban. Leban Sci J 4:67-7

Submitted: April 25, 2013; Accepted: July 3, 2013

Proofs received from author(s): August 27, 2013 